\title{
Utilization of Farm Pond and its Impact on Productivity under Krishi Bhagya Yojane
}

\author{
Rajendra Dayananda Gowda* and S. S. Dolli \\ Department of Agricultural Extension Education, College of Agriculture, Dharwad University \\ of Agricultural Sciences, Dharwad, Karnataka, India \\ *Corresponding author
}

The present study was conducted in the University of Agricultural Sciences, Dharwad during 2019-20 to study the "Utilization of farm pond and its impact on productivity under Krishi Bhagya Yojane". Eighty farmers formed sample for the study. The primary data Keywords

Krishi Bhagya Yojane (KBY), Farm pond, Irrigation, Farmers, Productivity

\section{Article Info}

Accepted: 04 December 2020 Available Online: 10 January 2021 about Utilization of farm pond and its impact on productivity under Krishi Bhagya Yojane, from farmers by using the schedule developed for the study. The results indicated that In kharif season majority of ginger growing farmers $(82.75 \%)$ gave 1 to 2 irrigation from collected runoff water for an average area of 1.69 acres and 73.68 per cent of maize growing farmers gave 1to 2 irrigation for an average area of 1.47 acres.In rabi season majority of the ginger growing farmers $(82.75 \%)$ irrigated 2 to 3 times for an average area of 1.69 acres followed by three fourth of ground nut growing of farmers $(75.00 \%)$ gave 2 to 3 irrigations for an average area of 1.54 acres. More than half of the farmers $(51.25 \%)$ filled their farm pond daily and less than half of the farmers $(48.75 \%)$ filled their farm pond weekly once. In case of cereals about 2.65 and 6.95 per cent of increase in productivity was observed in rice and maize due to implementation of farm pond respectively. In case oil seed like ground nut, the increase in productivity was up to 16.41 per cent after implementation of farm pond.The income from dairy animal cow before farm pond implementation was Rs.15702.35 and it had increased to Rs.18992.59 after farm pond implementation recording 20.95 per cent increase. Area under irrigation was increased from 3.57 to 4.12 acres recording a change of 15.40 per cent.

\section{Introduction}

A majority of the population in India exists in villages and above 50 per cent of them, relies on agriculture (directly or indirectly) and one of the greatest threats to farming is water scarcity. Rain fed agriculture constitutes 55 per cent of net sown area in the nation. The annual rainfall of the country varies from 400 $\mathrm{mm}$ to $>1200 \mathrm{~mm}$, varying both in place and time. In the low to medium rainfall rain-fed regions the occurrence of high intense rainfall events is very less i.e., only for the short duration. Hence the necessary rain water management is necessary to increase water efficiency. Since the first light of independence concerning efforts has been made to uplift the standards of farmers and 
rural masses to offer the solution that enables rain-fed farming towards sustainable farming.

Among several other states, Karnataka is important from the agriculture perspective, having a cultivable land area of 19 million hectares in which 15 million hectares depending on rainfall for cultivation (rain fed) and to overcome the drought-prone spot in dry affected areas and improve their agriculture livelihood the water has to be utilized strategically which can be caused by water harvesting.

Harvesting surplus runoff rainwater in dugout ponds and recycling the same using the motor and drip/sprinkler irrigation for providing supplementary irrigation to kharif crops or pre sown rabi crops has shown to be most successful technologies to combat the monsoon problems in India.

The challenge is to collect the runoff water from the farmer's field and use stored water for crops during the dry spell. With this insight the Government of Karnataka has started the flagship program, namely "Krishi Bhagya Yojane" (KBY) which is a pivotal step towards achieving sustainability of the rain-fed farmers of the state.

The KBY was implemented on 14-2-2014 in five prime dry land areas covering 23 districts. In 2014-15 it has been decided to implement in 9 lakh hectares of land to increase the agricultural productivity and income level of the farmers.

The primary purpose of the strategy is that harvested water in the farm ponds is being applied for providing lifesaving protective irrigation for rain-fed crops through sprinkler irrigation system; the polyethylene sheets are provided to prevent the percolation losses of the water in the farm ponds.

\section{Materials and Methods}

The study was an Ex-post facto research carried out purposively in Shivamogga and Uttara Kannada districts of Karnataka during 2019-20. Two Taluks from each district were selected based on higher number of farm pond beneficiaries. Twenty farmers from each taluk were selected (10 farmers having $<5$ acre of land and 10 farmers having $\geq 5$ acre of land), thus making total sample size of 80 , farmers selected based on purposive random sampling method.

\section{Utilization of water from farm pond for protective irrigation}

The numbers of irrigations given to various crops in respective seasons with area irrigated were recorded.

\section{Utilization of farm pond for storage of bore well water}

The farmers were asked to inform the season and frequency of filling farm pond as farmers makes use of farm pond for storing bore well water.

\section{Utilization of farm pond for fish rearing}

The number of fingerlings reared with their average yield and its income were recorded from the farmers who used farm pond for rearing fish.

\section{Impact of KBY on farm productivity}

Impact of $\mathrm{KBY}$ on farm productivity was studied by considering productivity of crops and as well as increased income of livestock before and after implementation of KBY. Area expansion under irrigation and cropped area after intervention of farm pond was recorded. 
The primary data about productivity of these enterprises was collected by using the schedule developed for the study.

\section{Results and Discussion}

\section{Utilization of water from farm pond for protective irrigation}

The results in the Table 1 revealed that majority of ginger growing farmers $(82.75 \%)$ provided one to two irrigation from collected runoff water for an average area of 1.69 acres during planting and vegetative growth stage of ginger in kharif season followed by 73.68 per cent of maize growing farmers provided 1to 2 irrigation at planting and knee height stage of maize for an average area of 1.47 acres, more than half of the pineapple growing farmers $(62.50 \%)$ at planting stage and 42.85 per cent paddy growing farmers provided 1 irrigation at transplanting or sowing stage of paddy for an average area of 1.62 acres and 1.23 acres respectively. This was due to the reason that in kharif there might be chance of failure in rain fall occurrence, at that time farmers used collected water for giving protective irrigation.

Further it was evident that in rabi season majority of ginger growing farmers $(82.75 \%)$ irrigated 2 to 3 times at rhizome developmental stage followed by three by fourth ground nut growing of farmers $(75.00$ $\%)$ provided 2 to 3 irrigations at sowing, vegetative and pegging stage of groundnut. Nearly three fourth of the banana growing farmers $(72.22 \%)$ provided 1 to 2 irrigation at vegetative and fruit development stage of banana, more than half of the pineapple $(62.50 \%)$ growing farmers provided 2 irrigations at fruit development stage, more than half number of chilli growing farmers $(61.53 \%)$ irrigated 1 to 2 times at planting and vegetative stage of chilli, almost equal per cent of tomato(58.88\%) growing and areca nut $(58.69 \%)$ growing farmers provided 1 to 2 irrigations at planting and vegetative development stage, less than half of the okra growing farmers (45.45\%) provided only 1irrigation at planting stage.

The results are on par with the study of Venuet al., (2015). They noted that Farm pond were being used for raising paddy nursery $(79.25 \%)$, followed by protective irrigation to paddy (77.36\%) and for drinking water for animals $(56.60 \%)$ and human beings $(37.74 \%)$.

\section{Utilization of farm pond for storage of bore well water}

The study observed that farmers use farm pond not only for collecting runoff water but also for storing bore well water. The results presented in the Table 2 indicated that all the farmers filled their farm pond in summer season by bore well water followed by 73.75 per cent of farmers filled their farm pond in rabi season by using bore well water. During kharif season, the pond was filled by rain water and the farmers take up rearing of fish but after rainy season they fill the pond by bore well water. As there will be no water after December month, farmers fill it up using bore well water and the water filled in farm pond is used when there is no power supply either by using diesel engine given under scheme or through gravity.

In the same table the data also shows that more than half number of farmers $(51.25 \%)$ filled their farm pond daily and less than half of the farmers (48.75\%) filled their farm pond weekly once. The reason behind farm pond filling daily was fish rearing. Farmers made use of farm pond as storage structure and they used to pump water to pond daily by bore well. Though technically it is not recommended but farmers find huge benefit 
of it by supplementing storage of bore well water.

\section{Utilization of farm pond in fish rearing}

The results in the Table 3 indicated that the farmers rearing 1500 fingerlings had harvested an average yield of $953 \mathrm{~kg}$ with an average income of Rs. 85,770 while farmers rearing 1000 fingerlings harvested an average yield of $752 \mathrm{~kg}$ with an average income of Rs. 67,680 and farmers rearing 500 fingerlings harvested an average yield of $425 \mathrm{~kg}$ with an average income of Rs. 38,250. The farmers were rearing different types of fish based on the feeding habits of fish like catla fish as surface feeder, rohu fish as column feeder and mrighal fish as bottom feeder. Data in table also reveals that as number of fingerlings increases the average yield and average income also increases but in decreasing proportion. This might be because as number of fishes increases the competition between them also increases for food and space.

The findings are in line with the study of Lekshmiet al., (2018). In their study on evaluation of farm ponds in agriculture, reported that the production of fish is increased after adaption of farm pond from $500 \mathrm{~kg}$ to 1 tonne.

Table.1 Utilization of water from farm pond for protective irrigation $n=80$

\begin{tabular}{|c|c|c|c|c|c|c|}
\hline $\begin{array}{l}\text { Sl. } \\
\text { No. }\end{array}$ & Season & Crop & $\begin{array}{c}\text { No. } \\
\text { farmers }\end{array}$ & $\begin{array}{c}\text { No. of } \\
\text { farmers used } \\
\text { farm pond } \\
\text { water }\end{array}$ & $\begin{array}{l}\text { Number of } \\
\text { irrigation }\end{array}$ & $\begin{array}{l}\text { Average } \\
\text { area } \\
\text { irrigated } \\
\text { (in acres) }\end{array}$ \\
\hline \multirow[t]{4}{*}{1} & \multirow[t]{4}{*}{ Kharif } & Paddy & 70 & $30(42.85)$ & 1 & 1.23 \\
\hline & & Maize & 38 & $28(73.68)$ & 1 to 2 & 1.47 \\
\hline & & Pineapple & 24 & $15(62.50)$ & 1 & 1.62 \\
\hline & & Ginger & 29 & $24(82.75)$ & 1 to 2 & 1.69 \\
\hline \multirow[t]{8}{*}{2} & \multirow[t]{8}{*}{ Rabi } & Groundnut & 20 & $15(75.00)$ & 2 to 3 & 1.54 \\
\hline & & Banana & 18 & $13(72.22)$ & 1 to 2 & 1.85 \\
\hline & & Areca nut & 46 & $27(58.69)$ & 1 to 2 & 2.09 \\
\hline & & Okra & 11 & $5(45.45)$ & 1 to 2 & 0.59 \\
\hline & & Chilli & 13 & $8(61.53)$ & 1 to 2 & 0.69 \\
\hline & & Tomato & 17 & $10(58.88)$ & 1 to 2 & 1.08 \\
\hline & & Pineapple & 24 & $15(62.50)$ & 2 & 1.62 \\
\hline & & Ginger & 29 & $24(82.75)$ & 2 to 3 & 1.69 \\
\hline
\end{tabular}

Note: Figures in parenthesis are percentage

Table.2 Utilization of farm pond for storage of bore well water $n=80$

\begin{tabular}{|c|l|c|c|}
\hline Sl. No. & Seasons of filling & Freq. & Percentage \\
\hline $\mathbf{1}$ & Rabi & 59 & 73.75 \\
\hline $\mathbf{2}$ & Summer & 80 & 100.00 \\
\hline & Frequency of filling & \multicolumn{2}{|c|}{} \\
\hline $\mathbf{1}$ & Weekly & 39 & 48.75 \\
\hline $\mathbf{2}$ & Daily & 41 & 51.25 \\
\hline
\end{tabular}


Table.3 Utilization of farm pond for fish rearing $n=80$

\begin{tabular}{|c|l|c|c|}
\hline $\begin{array}{c}\text { Sl. } \\
\text { No. }\end{array}$ & Category (fingerlings) & Average yield (kg) & Average income (Rupees) \\
\hline $\mathbf{1}$ & $500(\mathrm{n}=15)$ & 425 & 38,250 \\
\hline $\mathbf{2}$ & $1000(\mathrm{n}=12)$ & 752 & 67,680 \\
\hline $\mathbf{3}$ & $1500(\mathrm{n}=4)$ & 953 & 85,770 \\
\hline
\end{tabular}

Table.4 Impact of farm pond on crop productivity $n=80$

\begin{tabular}{|c|c|c|c|c|c|}
\hline \multirow[t]{2}{*}{$\begin{array}{l}\text { Sl. } \\
\text { No. }\end{array}$} & \multirow[t]{2}{*}{ Crop } & \multicolumn{2}{|c|}{$\begin{array}{l}\text { Productivity } \\
\text { (Qtl. /Acre) }\end{array}$} & \multirow[t]{2}{*}{$\begin{array}{l}\text { Percentage } \\
\text { change }\end{array}$} & \multirow[t]{2}{*}{$\begin{array}{l}\text { Paired t- } \\
\text { value }\end{array}$} \\
\hline & & Before FP & After FP & & \\
\hline 1 & $\begin{array}{l}\text { Paddy } \\
(\mathrm{n}=70)\end{array}$ & 13.25 & 13.60 & 02.65 & $0.742^{*}$ \\
\hline 2 & $\begin{array}{l}\text { Maize } \\
(\mathrm{n}=38)\end{array}$ & 14.67 & 15.69 & 06.95 & $0.776^{*}$ \\
\hline 3 & $\begin{array}{l}\text { Groundnut } \\
(\mathrm{n}=20)\end{array}$ & 10.54 & 12.27 & 16.41 & $1.234 * *$ \\
\hline 4 & $\begin{array}{l}\text { Okra } \\
(\mathrm{n}=11)\end{array}$ & 50.27 & 60.25 & 19.85 & $1.273 *$ \\
\hline 5 & $\begin{array}{l}\text { Chilli } \\
(\mathrm{n}=13)\end{array}$ & 78.36 & 85.13 & 08.63 & $0.786^{*}$ \\
\hline 6 & $\begin{array}{l}\text { Tomato } \\
(\mathrm{n}=17)\end{array}$ & 84.78 & 98.24 & 11.15 & $2.235^{*}$ \\
\hline 7 & $\begin{array}{l}\text { Banana } \\
(\mathrm{n}=18)\end{array}$ & 104.85 & 139.68 & 33.21 & $3.626^{* *}$ \\
\hline 8 & $\begin{array}{l}\text { Pineapple } \\
(\mathrm{n}=24)\end{array}$ & 151.29 & 170.44 & 12.65 & $3.865^{* * *}$ \\
\hline 9 & $\begin{array}{l}\text { Ginger } \\
(\mathrm{n}=29)\end{array}$ & 130.30 & 154.45 & 18.53 & $2.757^{* * *}$ \\
\hline 10 & $\begin{array}{l}\text { Pepper } \\
(\mathrm{n}=20)\end{array}$ & 4.23 & 04.56 & 07.83 & $3.709 *$ \\
\hline 11 & $\begin{array}{l}\text { Cashew } \\
(\mathrm{n}=12)\end{array}$ & 07.86 & 08.70 & 10.68 & $3.912^{\mathrm{NS}}$ \\
\hline 12 & $\begin{array}{l}\text { Mango } \\
(\mathrm{n}=13)\end{array}$ & 89.48 & 92.82 & 03.73 & $0.515^{\mathrm{NS}}$ \\
\hline 13 & $\begin{array}{l}\text { Areca nut } \\
(\mathrm{n}=46)\end{array}$ & 10.95 & 11.94 & 09.04 & $5.509 *$ \\
\hline
\end{tabular}


Table.5 Impact of farm pond on livestock $n=80$

\begin{tabular}{|c|l|c|c|c|c|}
\hline $\begin{array}{c}\text { Sl. } \\
\text { No. }\end{array}$ & Type of Animal & \multicolumn{2}{|c|}{ Income (Rupees) } & Percentage & Paired t- value \\
\cline { 2 - 5 } change & \\
\hline $\mathbf{1}$ & Cow $(\mathrm{n}=45)$ & 15702.35 & 18992.59 & 20.95 & $4.055^{*}$ \\
\hline $\mathbf{2}$ & Buffalo $(\mathrm{n}=36)$ & 20886.87 & 24611.12 & 17.83 & $6.341^{*}$ \\
\hline $\mathbf{3}$ & Sheep/Goat $(\mathrm{n}=15)$ & 13743.58 & 15705.12 & 14.27 & $2.856^{*}$ \\
\hline
\end{tabular}

** - Significant at 1 per cent

* - Significant at 5 per cent

Table.6 Impact of farm pond on expansion of irrigated area and cropped area $\mathrm{n}=80$

\begin{tabular}{|c|l|c|c|c|c|}
\hline \multirow{2}{*}{$\begin{array}{c}\text { Sl. } \\
\text { No. }\end{array}$} & \multicolumn{2}{|c|}{ Area (Acres) } & Percentage & Paired t- value \\
\cline { 2 - 5 } & & Before FP & After FP & change & \\
\hline $\mathbf{1}$ & Area irrigated & 03.57 & 04.12 & 15.40 & $5.661 * *$ \\
\hline $\mathbf{2}$ & Cropped area & 07.81 & 08.34 & 6.78 & $4.341^{*}$ \\
\hline **- Significant at 1 per cent & & & & \\
* - Significant at 5 per cent & & & & \\
\hline
\end{tabular}

\section{Impact of farm pond on crop productivity}

It is clear from the results in the Table 4 that in case of cereals about 2.65 and 6.95 per cent of increase in productivity was observed in rice and maize respectively due to implementation of farm pond. In case of oil seed like ground nut, the increase in productivity was up to 16.41 per cent after implementation of farm pond. Since both cereals and oil seeds are annual crops in nature and their roots are shallower so these crops dependent only on external source of water. Increase in productivity of these crops may be because of the reason that additional number of irrigations given from stored water at critical stage of the crops like tillering and panicle initiation in rice and branching and flowering stages in maize. Providing irrigation at flowering, peg penetration and pod development stages of ground nut increased the yield of ground nut.

In case of vegetables about 19.85, 8.63 and 11.15 per cent increase in productivity was observed in okra, chilli and tomato after farm pond implementation these is because of the reason that additional number of irrigations given in rabi season. And the productivity of fruit crops like banana and pineapple was also increased by 33.21 and 12.65 per cent after the farmers adopted farm pond the reason behind this change may be the fruit crops known for high yielding crops and additional water application also leads to high yield.

It is evident from the table that in case of commercial crops $18.53,7.83,10.68,3.73$ and 9.04 per cent increase in the productivity of ginger, pepper, cashew, mango and areca nut was recorded respectively by farmers after adopting farm pond. If we look into these results it is clear that the change in productivity is more compared to cereals because these plantation crops are deep rooted and they can get ground water easily than cereals.

The results of the paired ' $t$ ' test showed positive and significant effect of KBY on productivities of groundnut, banana, pineapple, ginger, paddy, maize, okra, chilli, tomato, pepper and areca nut because of the reason that the collected water from the farm 
pond helped in change in the productivity of crops.

The findings are in line with the study of Moulasab et al., (2018) on Krishi Bhagya Scheme: An impact study for improvement of livelihood of the farmer. They noticed that there is 17 to 53 per cent of increase of average yield of crops due to implementation of farm pond. Desai et al., (2006) in their study indicated that the percentage in the crop productivity was considerably high with farm pond that is 16 per cent to 41 per cent.

\section{Impact of farm pond on livestock}

The results in Table 5 depicts that there is 20.95 per cent of increase in income from cow after farm pond implementation followed by 17.83 per cent increase in income from buffalo and 14.27 per cent increase in the income from the sheep/goat. Given the strong presence of dairy cooperatives, milk from cows/buffaloes is sold which contributes to revenues from the livestock. The availability of water post-intervention has allowed farmers to grow maize, napier and fodder sorghum which is used as fodder for livestock and reduced some expenses. Further increased the yield of milk and quantity of FYM due to which returns from livestock also increased.

The results of the paired ' $t$ ' test showed positive and significant effect of KBY on income from cow, buffalo and sheep/ goat because of the reason that the collected water from farm pond helped in change the income from livestock.

The findings are on par with the study of Desai et al., (2006). In their study on Impact assessment of farm-ponds, indicated that the income from livestock was increased from Rs. $1,880.32$ to Rs. $1,692.26$ with a 1.66 per cent change.
Impact of farm pond on expansion of irrigated area and cropped area

The results in the Table 6 indicated that about 15.40 per cent of incremental change can be seen in irrigated area after farm pond implementation. It due to the fact that farm pond adopted by farmer serves as water storage structure due to which water availability was more and dry land was also converted into irrigated land by using the stored water.

By looking at the results in the same table it is evident that 6.78 per cent of increase in the cropped area is because of the reason that farm pond adopted by farmer can irrigate more crops with proper scheduling and farmer can take up growing more crops in rabi and summer season because water availability in farm pond was more compared to days before adoption of farm pond.

The results of the paired ' $t$ ' test showed positive and significant effect of KBY on expansion of irrigated and cropped area because the water collected and utilised by the farmer directly influences the change in irrigation and cropped area

\section{References}

Desai R, Patil B L, Kunnal L B, Jayashree H and Basavaraj H, 2006, Impact assessment of farm ponds in Dharwad district of Karnataka. Karnataka Journal Agricultural Sciences, 20(2): 426-427.

Lekshmi G S, Saravanan E and Shaji P K, 2018, Evaluation of farm ponds on agriculture in Pattancherypanchayat of Palakkad district, Kerala, India. IOSR Journal Humanities and Social Science, 23(9): 18-20.

MoulasabMeti S K and Ashoka M B, 2018, Krishi Bhagya scheme: An impact study 
for improvement of livelihood of the farmers in Hyderabad-Karnataka region, India. International Journal of Current Microbiology and Applied Sciences, 7(7): 565-570.

Venu B N, Ravi Simha L and Venkataramana
R V, 2015, Economic analysis of farm ponds in Tungabhadra project command area of Karanataka, India. International Journal of Agricultural Science and Research, 5(3): 193-198.

\section{How to cite this article:}

Rajendra Dayananda Gowda and Dolli, S. S. 2021. Utilization of Farm Pond and its Impact on Productivity under Krishi Bhagya Yojane. Int.J.Curr.Microbiol.App.Sci. 10(01): 426-433. doi: https://doi.org/10.20546/ijcmas.2021.1001.052 